\title{
Effects of gender and age on energy use by young Boer goats
}

\author{
I. Tovar-Luna ${ }^{\mathrm{a}, \mathrm{b}}$, R. Puchala ${ }^{\mathrm{a}}$, T. Sahlu ${ }^{\mathrm{a}}$, A.L. Goetsch ${ }^{\mathrm{a}, *}$ \\ a American Institute for Goat Research, Langston University, Langston, OK, USA \\ ${ }^{\mathrm{b}}$ Universidad Autónoma Chapingo, Chapingo, Mexico
}

\section{A R T I C L E I N F O}

\section{Keywords:}

Age

Energy

Gender

Goats

Maintenance

\begin{abstract}
A B S T R A C T
Boer goats (7/8 and 1/8 Spanish breed) were used to characterize effects of gender and age on the ME requirement for maintenance $\left(\mathrm{ME}_{\mathrm{m}}\right)$. There were eight animals of each gender, doelings, intact males, and wethers castrated at 2 mo of age. Kids were weaned at 3.7 mo and thereafter consumed a $50 \%$ concentrate pelleted diet ad libitum while in group pens at most times. Measurement periods consisted of three segments of 12,10 , and 4 days with consumption ad libitum and near $\mathrm{ME}_{\mathrm{m}}$ and while fasting, respectively. Maintenance segment measures began at 4.9, 7.8, 11.7, and 14.8 mo of age in periods $1,2,3$, and 4, respectively. Feed intake data, feces and urine collections, and a calorimetry system were used to determine ME intake and heat energy (HE). The $\mathrm{ME}_{\mathrm{m}}$ estimate was based on fasting $\mathrm{HE}$ and the slope $\left(\mathrm{k}_{\mathrm{m}}\right)$ of the regression of recovered energy (RE) against ME intake with intake near $\mathrm{ME}_{\mathrm{m}}$ and while fasting, and $\mathrm{k}_{\mathrm{g}}$ was $\mathrm{RE}$ with ad libitum intake relative to ME intake above $\mathrm{ME}_{\mathrm{m}}$. BW (kg) during the maintenance segment was 20.6, 30.8, 46.5, and 57.1 for doelings, 25.9, $40.1,67.3$, and 76.9 for males, and $23.1,35.1,53.9$, and 65.0 for wethers in periods $1,2,3$, and 4 , respectively $(\mathrm{SE}=1.85) . \mathrm{k}_{\mathrm{m}}$ was similar among genders and periods $(\mathrm{P}>0.05 \% ; 70.2 \%, 69.5 \%$, and $69.7 \%$ for doelings, males, and wethers, respectively; $\mathrm{SE}=1.25)$. Fasting $\mathrm{HE}$ and $\mathrm{ME}_{\mathrm{m}}$ were affected by gender $\times$ period interactions $(\mathrm{P}<0.001)$. Fasting HE $\left(\mathrm{kJ} / \mathrm{kg} \mathrm{BW}^{0.75}\right)$ was 277, 272, 281, and 281 for doelings, 288, 327, 334, and 398 for males, and 274, 303, 274, and 305 for wethers $(\mathrm{SE}=10.1) ; \mathrm{ME}_{\mathrm{m}}\left(\mathrm{kJ} / \mathrm{kg} \mathrm{BW}^{0.75}\right)$ was 382, 390, 399, and 420 for doelings, 412, 469, 492, and 569 for males, and 384, 417, 426, and 439 for wethers in periods $1,2,3$, and 4, respectively $(S E=14.2) . \mathrm{k}_{\mathrm{g}}$ tended $(\mathrm{P}=0.067)$ to vary among genders $(61.5 \%, 48.1 \%$, and $52.7 \%$ for doelings, males, and wethers, respectively; $\mathrm{SE}=3.91$ ). In conclusion, $\mathrm{ME}_{\mathrm{m}}$ was not greatly different between doelings and wethers and increased for both as the study progressed, whereas that for males was greater, with the difference increasing considerably as age rose.
\end{abstract}

\section{Introduction}

Energy and nutrient requirements of livestock are difficult to address both in terms of original research and for committees charged with summarizing available information and providing recommendations to be of value in many areas. This is particularly challenging for goats because of the wide range of conditions they are able to survive in and produce under and the multitude of factors affecting their requirements.

One of the limitations of the nutrient requirement recommendations for goats of Sahlu et al. (2004) and NRC (2007), as well as of other scientific committees, is potential influence of gender. Research on which energy requirements of goats presented by NRC (2007) was based dealt with databases of treatment mean observations constructed from publications available in the literature that contained suitable intake and performance information. This approach was taken so that the databases were broad and application of the findings could be widespread, albeit with appropriate adjustments. This is converse to focus on a few studies under a limited number of conditions with variable methodologies that could lead to questionable extrapolation to different settings. However, as addressed by Sahlu et al. (2004) and NRC (2007), an excessive number of publications used in constructing the databases did not clearly address gender and there were inadequate studies available that specifically targeted potential effects of gender. Thus, recommendations of NRC (2007) to address gender differences in the energy requirement for maintenance were ones previously proposed for other ruminant species, namely similar values for females and wethers and ones $15 \%$ greater for intact males.

Need for research to address this information void and evaluate these assumptions has been frequently stated since publication of NRC (2007), notable examples being Sahlu et al. (2009) and Tedeschi et al. (2010). In this regard, recently Almeida et al. (2015) did not observe differences in $\mathrm{ME}_{\mathrm{m}}$ among female, male, and wether Saanen goats over a 15-kg range in BW and time period of 3.5-4 mo by comparative

\footnotetext{
* Corresponding author.

E-mail address: goetsch@langston.edu (A.L. Goetsch).
} 
slaughter with different levels of feed intake. The primary objective of the present experiment was to characterize $\mathrm{ME}_{\mathrm{m}}$ of Boer goats over wide ranges of age and BW and managed under fairly conventional production conditions.

\section{Materials and methods}

\subsection{Animals, periods, and measures}

The experimental protocol was approved by the Langston University Animal Care and Use Committee. Twenty-four meat goat kids born in the study of Tovar-Luna et al. (2011), 7/8 Boer and 1/8 Spanish, were used. Eight males were castrated at 65 days of age, and there were eight males left intact and eight doelings. Kids were weaned at $111 \pm 0.2$ days of age, treated for internal parasites, and housed in a facility with individual $1.05 \times 0.55 \mathrm{~m}$ elevated pens with a plastic-coated expanded metal floor until measurements were completed in period 2 . Water was available free-choice and feed was offered at 08:00 and 18:00 h. Thereafter, animals were situated by gender in $6.1 \times 5.6 \mathrm{~m}$ pens in an enclosed building that had a $6.1 \times 1.35 \mathrm{~m}$ area with a concrete floor and a $6.1 \times 4.25 \mathrm{~m}$ unpaved floor area when measurements were not underway. Automated waterers were used, pine shavings were periodically added as bedding, and each pen had an automated feeding unit allowing ad libitum intake (MK 3 FIRE, Feed Intake Recording Equipment; Osborne Industries, Inc., Osborne, KS, USA).

Most measurement periods consisted of three segments of 12, 10, and 4 days with consumption ad libitum and near the ME requirement for maintenance $\left(\mathrm{ME}_{\mathrm{m}}\right)$ and while fasting, respectively. Feed offered was gradually increased for $1 \mathrm{wk}$ after fasting to avoid digestive upset. Maintenance phase measures began at $148 \pm 1.5,236 \pm 1.3$, $355 \pm 1.1$, and $450 \pm 1.99$ days (i.e., 4.9, 7.8, 11.7, and $14.8 \mathrm{mo}$, respectively). For the first part of each segment, goats were housed individually in the $1.05 \times 0.55 \mathrm{~m}$ elevated pens. Thereafter during collection of feces and urine and gas exchange measurements, goats were situated in metabolism crates $(0.7 \times 1.2 \mathrm{~m}$; plastic-coated expanded metal floor).

The diet was offered at approximately $120 \%$ of consumption on the preceding few days when intake was ad libitum. The rate of feeding ME near the $\mathrm{ME}_{\mathrm{m}}$ requirement was $489 \mathrm{~kJ} / \mathrm{kg} \mathrm{BW}{ }^{0.75}$, and the amount of DM offered was based on assumed concentrations of $60 \%$ TDN and 9.1 $\mathrm{MJ} / \mathrm{kg}$ ME for the diet shown in Table 1. However, the ad libitum intake segment of period 4 was omitted because intake was not markedly different from that near the assumed $\mathrm{ME}_{\mathrm{m}}$ requirement. In addition, subsequent measures occurred at $631 \pm 2.6$ and $826 \pm$ days of age (20.8 and 27.2 mo of age, respectively) in periods 5 and 6 , respectively. However, because of different management conditions after period 4, with housing by gender in small outside pens and free-choice feeding of the same diet, BW declined and was lower during period 5 measures than in period 4. As a consequence, $\mathrm{ME}_{\mathrm{m}}$ estimates were lower than earlier and, thus, are not reported. Body weight during measurements in period 6 had increased considerably from that in period 5 and was similar or greater than values in period 4. Period $6 \mathrm{ME}_{\mathrm{m}}$ estimates are presented, but because of a lesser number of observations $(7,5$, and 5 for doelings, males, and wethers, respectively) are only briefly compared with values in period 4.

Excreta collection occurred on the last 5 days of ad libitum and $\mathrm{ME}_{\mathrm{m}}$ segments, and gas exchange measures were on the final 2 days of the segments. Animals began measurement periods sequentially so that there was one or two of each gender assessed for gas exchange at the same time. Urine was acidified with $20 \mathrm{ml}$ of 0.2 ( $\mathrm{vol} / \mathrm{vol}) \mathrm{H}_{2} \mathrm{SO}_{4}$ placed in each collection vessel to maintain $\mathrm{pH}$ below 3.0. Composite samples of feces and urine were formed by collecting $10 \%$ daily aliquots, and samples were stored at $-20{ }^{\circ} \mathrm{C}$. Feed was sampled daily during measurements to form four composite samples at each age. Feed and fecal samples were analyzed for DM (ID 9560.03; AOAC, 2006), ash (942.05; AOAC, 2006), nitrogen (Leco TruMac CN, St. Joseph, MI), NDF
Table 1

Ingredient composition of a $50 \%$ concentrate pelleted diet and chemical composition of feedstuffs fed to growing meat goats.

\begin{tabular}{ll}
\hline Item & \\
\hline Ingredient (\%, as fed basis) & \\
$\quad$ Dehydrated alfalfa & 19.98 \\
Cottonseed hulls & 29.07 \\
Cottonseed meal & 15.99 \\
Ground corn & 15.99 \\
Wheat middlings & 9.99 \\
Pelletizing agent & 5.00 \\
Trace mineralized salt ${ }^{\mathrm{a}}$ & 0.50 \\
Salt & 0.50 \\
Yeast & 1.00 \\
Calcium carbonate & 0.95 \\
Ammonium chloride & 1.00 \\
Vitamin A premix & \\
Rumensin 80 premix & \\
& 002 \\
Chemical composition & 0.01 \\
OM (\% DM) & \\
CP (\% DM) & $92.2 \pm 0.06$ \\
NDF \% DM) & $16.4 \pm 0.15$ \\
Gross energy (MJ/kg DM) & $44.8 \pm 0.44$ \\
\hline a Contained 95-98\% NaCl and at least $0.24 \% \mathrm{Mn}, 0.24 \% \mathrm{Fe}, 0.05 \% \mathrm{Mg}$ \\
0.032\% Cu, 0.011\% Co, 0.007\% I, and 0.005\% Zn. \\
b Contained 66,200 IU/kg. \\
c $17.6 \%$ monensin. \\
$\quad$ \\
\hline
\end{tabular}

with use of heat stable amylase (Van Soest et al., 1991) and containing residual ash (filter bag technique of ANKOM Technology Corp., Fairport, NY), and gross energy (GE) using a bomb calorimeter (Parr 6300; Parr Instrument Co., Inc., Moline, IL). Urine samples were analyzed for DM (lyophilization), and nitrogen and GE concentrations in lyophilized urine samples were determined as described above.

Body weight was determined at the beginning of each segment and at the start and end of the 2 days of gas exchange measurements. Gas exchange occurred in a room with four metabolism cages fitted with head-boxes of an indirect, open-circuit respiration calorimetry system (Sable Systems International, Las Vegas, NV, USA). Heat energy (HE) was determined as in other studies (Puchala et al., 2007, 2009). Oxygen concentration was analyzed using a fuel cell FC-1B $\mathrm{O}_{2}$ analyzer (Sable Systems International), and $\mathrm{CH}_{4}$ and $\mathrm{CO}_{2}$ concentrations were measured with infrared analyzers (CA-1B for $\mathrm{CO}_{2}$ and MA-1 for $\mathrm{CH}_{4}$; Sable Systems International). Prior to gas exchange measurements, analyzers were calibrated with gases of known concentrations. Ethanol combustion tests were performed to ensure complete recovery of $\mathrm{O}_{2}$ and $\mathrm{CO}_{2}$ produced with the same flow rates as used during measurements. Heat energy was determined according to the Brouwer (1965) equation. Energy lost in $\mathrm{CH}_{4}$ was total $\mathrm{CH}_{4}$ emitted in L/day $\times 39.5388 \mathrm{~kJ} / \mathrm{L}$ (Brouwer, 1965), and ME was the difference between DE and the sum of energy in urine and methane. Recovered energy (RE) was the difference between ME intake (MEI) and HE. Heat energy was expressed relative to average $\mathrm{BW}^{0.75}$ within the 2-day assessment periods. Average daily gain between $\mathrm{BW}$ at birth and period 1 and between subsequent periods was determined based on average BW during the gas exchange measurement period with intake near the $\mathrm{ME}_{\mathrm{m}}$ requirement.

\subsection{Calculations and statistical analyses}

There were some missing observations because of factors including equipment malfunction, occasional health issues, length of measurement period constraints in regards to other experimentation with the same facilities and equipment, data collection mishaps, etc. It was felt preferable in terms of accuracy to include all potential observations as shown in Table 2 rather than only those for animals having estimates for all variables in each period.

The efficiency of energy use for $\mathrm{ME}_{\mathrm{m}}\left(\mathrm{k}_{\mathrm{m}}\right)$ was determined by 
Table 2

Numbers of observations.

\begin{tabular}{|c|c|c|c|c|c|c|}
\hline \multirow[b]{2}{*}{ Item $^{c}$} & \multirow[b]{2}{*}{ Gender } & \multirow[b]{2}{*}{ Intake level } & \multicolumn{4}{|c|}{ Period $^{\mathrm{a}, \mathrm{b}}$} \\
\hline & & & 1 & 2 & 3 & 4 \\
\hline \multirow[t]{3}{*}{ BW } & Doeling & & 8 & 8 & 8 & 7 \\
\hline & Male & & 7 & 7 & 7 & 7 \\
\hline & Wether & & 7 & 8 & 8 & 6 \\
\hline \multirow[t]{3}{*}{ ADG } & Doeling & & 8 & 8 & 8 & 7 \\
\hline & Male & & 7 & 7 & 7 & 7 \\
\hline & Wether & & 7 & 7 & 8 & 6 \\
\hline \multirow[t]{6}{*}{ Intake and digestion measures } & Doeling & Ad libitum & 8 & 7 & 8 & \\
\hline & Doeling & Near $\mathrm{ME}_{\mathrm{m}}$ & 8 & 7 & 8 & 7 \\
\hline & Male & Ad libitum & 8 & 7 & 8 & \\
\hline & Male & Near $\mathrm{ME}_{\mathrm{m}}$ & 8 & 7 & 7 & 7 \\
\hline & Wether & Ad libitum & 8 & 7 & 8 & \\
\hline & Wether & Near $\mathrm{ME}_{\mathrm{m}}$ & 8 & 7 & 8 & 7 \\
\hline \multirow[t]{3}{*}{$\mathrm{FHP}, \mathrm{k}_{\mathrm{m}}$, and $\mathrm{ME}_{\mathrm{m}}$} & Doeling & & 8 & 8 & 8 & 7 \\
\hline & Male & & 7 & 7 & 7 & 7 \\
\hline & Wether & & 7 & 7 & 8 & 6 \\
\hline \multirow[t]{3}{*}{$\mathrm{k}_{\mathrm{g}}$} & Doeling & & 7 & 8 & 8 & \\
\hline & Male & & 7 & 7 & 7 & \\
\hline & Wether & & 6 & 6 & 8 & \\
\hline
\end{tabular}

a Measurement periods consisted of three segments of 12,10 , and 4 days for consumption ad libitum and near the ME requirement for maintenance and while fasting, respectively.

${ }^{\mathrm{b}}$ Maintenance segment measures began at 4.9, 7.8, 11.7, and 14.8 mo of age, respectively.

${ }^{\mathrm{c}} \mathrm{FHP}=$ fasting heat production; $\mathrm{k}_{\mathrm{m}}=$ efficiency of ME utilization for maintenance; $\mathrm{ME}_{\mathrm{m}}=\mathrm{ME}$ requirement for maintenance; $\mathrm{k}_{\mathrm{g}}=$ efficiency of $\mathrm{ME}$ utilization for gain.

regressing $\mathrm{RE}$ against $\mathrm{ME}$ intake (MEI) during $\mathrm{ME}_{\mathrm{m}}$ and fasting segments, with $\mathrm{ME}_{\mathrm{m}}$ of each animal derived from dividing fasting $\mathrm{HE}$ (FHE) by $\mathrm{k}_{\mathrm{m}}$. Metabolizable energy used for gain $\left(\mathrm{ME}_{\mathrm{g}}\right)$ in periods 1,2 , and 3 with ad libitum intake was estimated as the difference between MEI and $\mathrm{ME}_{\mathrm{m}}$. Recovered energy with ad libitum intake used for tissue gain $\left(R E_{g}\right)$ regressed against $M E_{g}$ with ad libitum intake and when fed near maintenance, assuming that $\mathrm{ME}_{\mathrm{g}}$ and $\mathrm{RE}_{\mathrm{g}}$ were 0 , yielded the efficiency of energy use for tissue energy accretion $\left(\mathrm{k}_{\mathrm{g}}\right)$. This estimate of $\mathrm{k}_{\mathrm{g}}$ is the same as simply dividing $\mathrm{RE}_{\mathrm{g}}$ by $\mathrm{ME}_{\mathrm{g}}$ when animals consumed the diet ad libitum. Relatedly, regressing $\mathrm{RE}_{\mathrm{g}}$ against $\mathrm{ME}_{\mathrm{g}}$ with ad libitum intake and intake near $\mathrm{ME}_{\mathrm{m}}$ without setting $\mathrm{RE}_{\mathrm{g}}$ at 0 with near $\mathrm{ME}_{\mathrm{m}}$ intake resulted in some unrealistic $\mathrm{k}_{\mathrm{g}}$ estimates (i.e., negative or above $100 \%$ ). Most likely this was because of the application of an efficiency of energy utilization based on both tissue mobilization while fasting and primarily use of dietary ME for maintenance when fed near $\mathrm{ME}_{\mathrm{m}}$ to any differences between the estimate of $\mathrm{ME}_{\mathrm{m}}$ and actual MEI when fed near $\mathrm{ME}_{\mathrm{m}}$.

Data were analyzed with mixed effects models (Littell et al., 1996) with the repeated measure of period and random effect of animal within gender. Fixed effects were gender, period, and their interaction.
Main effects and their means were addressed when the interaction was nonsignificant $(\mathrm{P}>0.05)$ and interaction means were presented when the interaction was significant $(\mathrm{P}<0.05)$. Separation of BW, ADG, and energy measure means was through orthogonal contrasts for linear and quadratic effects of period or increasing age. It was assumed that ages were equally spaced, since testing of the actual spacing with the IML procedure of SAS (2004) indicated negligible effect. To evaluate effects of level of intake on digestibility measures, estimates with intake near the $\mathrm{ME}_{\mathrm{m}}$ requirement in period 4 were omitted, with period $4 \mathrm{ME}_{\mathrm{m}}$ data analyzed by the GLM procedure of SAS (2004). This model included gender, period, level of intake, two-way interactions, and the three way interaction, with the repeated measure of period $\times$ intake level and means separation by least significant difference with a protected F-test $(\mathrm{P}<0.05)$.

Homogeneity of variance was evaluated with the Bartlett test of SAS (2004). To evaluate energetically optimal body size as described by Hannon and Murphy (2016), HE of different periods in MJ/day while fasting and consuming feed ad libitum and near $\mathrm{ME}_{\mathrm{m}}$ and the $\mathrm{ME}_{\mathrm{m}}$ estimate were regressed against linear, quadratic, and cubic functions of BW without and with model inclusion of gender and level of intake. Pearson correlation coefficients were determined for some energy measures with the CORR procedure of SAS (2004).

\section{Results}

\section{1. $B W$ and $A D G$}

There were interactions $(\mathrm{P}<0.001)$ between gender and period in BW and ADG (Table 3). As expected, increases in BW as the trial advanced ranked males $>$ wethers $>$ doelings. The interaction in ADG was primarily because of relatively high values for males in periods 2 and 3, particularly the latter. Body weight in period 6 for doelings $(57.7 \pm 2.13 \mathrm{~kg})$ and males $(74.0 \pm 2.49 \mathrm{~kg})$ was similar to values in period 4, although wethers were slightly heavier $(P=0.005)$ in period 6 $(70.7 \pm 2.20 \mathrm{~kg})$.

\subsection{Intake and digestion}

There were no three-way interactions in intake or digestibility measures ( $P>0.05$; Tables 4 and 5 ). Dry matter intake was affected by interactions between level of intake and gender and period $(P \leq 0.01)$. The former interaction was because of greater gender differences when intake was ad libitum than near $\mathrm{ME}_{\mathrm{m}}$, at least particularly reflective of differences in BW and ADG. The interaction in DM intake appeared due primarily to a less than expected value in period 2 with ad libitum intake, which corresponds to similar ADG from birth to period 1 and between periods 1 and 2 compared with ADG from period 2-3. Digestibility of DM was greater for wethers than for males $(P<0.05)$, with an intermediate value for doelings ( $P>0.05)$, and was

Table 3

Effects of gender and age on BW and ADG of Boer goats.

\begin{tabular}{|c|c|c|c|c|c|c|c|c|c|c|c|c|}
\hline \multirow[b]{2}{*}{ Item } & \multicolumn{3}{|c|}{ Effect $P$ value ${ }^{a}$} & \multirow[b]{2}{*}{ GN } & \multicolumn{3}{|c|}{ Period contrast $\mathrm{P}$ values ${ }^{\mathrm{b}}$} & \multicolumn{4}{|c|}{ Period $^{\mathrm{c}, \mathrm{d}}$} & \multirow[b]{2}{*}{ SE } \\
\hline & GN & PR & $\mathrm{GN} * \mathrm{PR}$ & & Linear & Quadratic & Cubic & 1 & 2 & 3 & 4 & \\
\hline \multirow[t]{3}{*}{ BW (kg) } & $<0.001$ & $<0.001$ & $<0.001$ & Doeling & $<0.001$ & 0.875 & 0.015 & 20.6 & 30.8 & 46.5 & 57.1 & 1.85 \\
\hline & & & & Male & $<0.001$ & 0.027 & $<0.001$ & 25.9 & 40.1 & 67.3 & 76.9 & \\
\hline & & & & Wether & $<0.001$ & 0.624 & 0.001 & 23.1 & 35.1 & 53.9 & 65.0 & \\
\hline \multirow[t]{3}{*}{ ADG (g) } & $<0.001$ & $<0.001$ & $<0.001$ & Doeling & 0.575 & 0.134 & 0.101 & 118 & 116 & 134 & 104 & 9.9 \\
\hline & & & & Male & 0.073 & $<0.001$ & $<0.001$ & 149 & 162 & 227 & 107 & \\
\hline & & & & Wether & 0.555 & 0.123 & 0.041 & 139 & 134 & 158 & 122 & \\
\hline
\end{tabular}

a $\mathrm{GN}=$ gender; $\mathrm{PR}=$ period.

${ }^{\mathrm{b}}$ Linear, quadratic, and cubic effects of period.

${ }^{c}$ Measurement periods consisted of three segments of 12, 10, and 4 days for consumption ad libitum and near the ME requirement for maintenance and while fasting, respectively.

${ }^{\mathrm{d}}$ Maintenance segment measures began at 4.9, 7.8, 11.7, and 14.8 mo of age in period 1, 2, 3, and 4, respectively. 
Table 4

$\mathrm{P}$ values for effects of gender and age on intake and digestion in Boer goats.

\begin{tabular}{|c|c|c|c|c|c|c|c|}
\hline \multirow[b]{2}{*}{ Item } & \multicolumn{7}{|c|}{ Effect $P$ values ${ }^{\mathrm{a}}$} \\
\hline & GN & PR & $\mathrm{GN} * \mathrm{PR}$ & IL & GN*IL & $P R * I L$ & $\mathrm{GN}^{*} \mathrm{PR} * \mathrm{IL}$ \\
\hline \multicolumn{8}{|l|}{ DM } \\
\hline Intake (g/day) & 0.002 & $<0.001$ & 0.083 & $<0.001$ & 0.008 & 0.001 & 0.770 \\
\hline Digestion (\%) & 0.031 & 0.969 & 0.151 & $<0.001$ & 0.659 & 0.217 & 0.686 \\
\hline Digestion (g/day) & 0.03 & $<0.001$ & 0.004 & $<0.001$ & 0.049 & $<0.001$ & 0.341 \\
\hline \multicolumn{8}{|l|}{$\mathrm{OM}$} \\
\hline Intake (g/day) & 0.001 & $<0.001$ & 0.081 & $<0.001$ & 0.008 & 0.001 & 0.770 \\
\hline Digestion (\%) & 0.013 & 0.566 & 0.221 & $<0.001$ & 0.637 & 0.167 & 0.714 \\
\hline Digestion (g/day) & 0.003 & $<0.001$ & 0.005 & $<0.001$ & 0.050 & $<0.001$ & 0.351 \\
\hline \multicolumn{8}{|l|}{ Gross energy } \\
\hline Intake (MJ/day) & 0.001 & $<0.001$ & 0.065 & $<0.001$ & 0.009 & 0.001 & 0.777 \\
\hline Digestion (\%) & 0.014 & 0.451 & 0.236 & $<0.001$ & 0.638 & 0.006 & 0.754 \\
\hline Digestion (MJ/day) & 0.004 & $<0.001$ & 0.003 & $<0.001$ & 0.067 & $<0.001$ & 0.338 \\
\hline \multicolumn{8}{|l|}{ Methane } \\
\hline MJ/day & 0.096 & $<0.001$ & 0.879 & 0.062 & 0.936 & 0.012 & 0.895 \\
\hline$\%$ gross energy intake & 0.840 & $<0.001$ & 0.880 & $<0.001$ & 0.763 & 0.003 & 0.990 \\
\hline \multicolumn{8}{|l|}{ ME } \\
\hline Intake (MJ/day) & 0.002 & $<0.001$ & 0.002 & $<0.001$ & 0.020 & $<0.001$ & 0.118 \\
\hline Intake $\left(\mathrm{kJ} / \mathrm{kg} \mathrm{BW}^{0.75}\right)$ & 0.843 & $<0.001$ & 0.059 & $<0.001$ & 0.508 & $<0.001$ & 0.101 \\
\hline Concentration (MJ/kg DM) & 0.252 & 0.133 & 0.451 & $<0.001$ & 0.973 & 0.674 & 0.838 \\
\hline \multicolumn{8}{|l|}{$\mathrm{CP}$} \\
\hline Intake (g/day) & 0.001 & $<0.001$ & 0.025 & $<0.001$ & 0.009 & $<0.001$ & 0.788 \\
\hline Digestion (\%) & 0.164 & $<0.001$ & 0.252 & 0.314 & 0.672 & 0.823 & 0.075 \\
\hline Digestion (g/day) & 0.003 & $<0.001$ & 0.001 & $<0.001$ & 0.050 & $<0.001$ & 0.224 \\
\hline \multicolumn{8}{|l|}{ NDF } \\
\hline Intake (g/day) & 0.001 & $<0.001$ & 0.110 & $<0.001$ & 0.007 & 0.002 & 0.792 \\
\hline Digestion (\%) & 0.008 & $<0.001$ & 0.341 & $<0.001$ & 0.473 & 0.001 & 0.706 \\
\hline Digestion (g/day) & 0.005 & $<0.001$ & $<0.001$ & $<0.001$ & 0.493 & 0.003 & 0.083 \\
\hline Nitrogen balance (g/day) & 0.003 & $<0.001$ & 0.039 & $<0.001$ & 0.097 & 0.072 & 0.603 \\
\hline
\end{tabular}

${ }^{\text {a }} \mathrm{GN}=$ gender; $\mathrm{PR}=$ period; $\mathrm{IL}=$ intake level.

$7.2 \%$ units greater $(\mathrm{P}<0.05)$ with intake near the $\mathrm{ME}_{\mathrm{m}}$ requirement than ad libitum $(\mathrm{P}<0.05)$. Digestible DM intake was affected by all two-way interactions $(\mathrm{P} \leq 0.05)$, with those involving intake level due to corresponding ones in DM intake. However, the gender $\times$ period interaction was mainly because of similar values for wethers in periods 1 and 2 in contrast to greater values in period 2 for males and doelings.

Results for OM, GE, and NDF intake and digestibilities in periods 1 , 2 , and 3 were similar to those for DM, except for interactions between intake level and period in digestibility of GE and NDF $(\mathrm{P}=0.01$; Tables 4 and 5). These interactions appeared due mainly to lower values in period 3 vs. 1 with ad libitum intake compared with similar values among periods with intake near $\mathrm{ME}_{\mathrm{m}}$. Intake of $\mathrm{ME}$ relative to $\mathrm{BW}^{0.75}$ was affected by an interaction between level of intake and period ( $\mathrm{P}<0.001$ ), which was because of a greater value for period $1 \mathrm{vs.} 2$ and 3 with ad libitum intake and lower and similar values among periods with intake near $\mathrm{ME}_{\mathrm{m}}$. Intake of $\mathrm{DM}$ was $1038 \pm 31.1,1280 \pm 42.3$, and $21186 \pm 81.2 \mathrm{~g} /$ day, DM digestibility was $64.2 \pm 0.59$, $64.6 \pm 0.96$, and $62.2 \pm 1.98 \%$, and digestible DM intake was $666 \pm 20.5,826 \pm 27.1$, and $743 \pm 66.9 \mathrm{~g} /$ day for doelings, males, and wethers, respectively, in period 4 . The diet ME concentration in periods 1,2 , and 3 was $8.5 \%$ greater with intake near $\mathrm{ME}_{\mathrm{m}}$ than ad libitum.

Intake of $\mathrm{CP}$ was affected $(\mathrm{P} \leq 0.03)$ by each two-way interaction, similar to many of the aforementioned interactions (Tables 4 and 5). Only period affected $(\mathrm{P}<0.001) \mathrm{CP}$ digestion, with values ranking period $2<1<3$. Digestible CP intake was also impacted by all twoway interactions $(\mathrm{P} \leq 0.05)$. Differences among genders and between intake levels were relatively greater in period 3 vs. periods 1 and 2 and the difference between intake levels was slightly greater for males than for doelings and wethers. Nitrogen balance estimates were relatively high and suggest unaccounted for $\mathrm{N}$ loss(es). Nonetheless, as expected the value was greater with ad libitum vs. restricted feed intake
$(\mathrm{P}<0.001)$ and the magnitude of difference between males and doelings and wethers was much greater in period 3 than in periods 1 or 2 .

\subsection{Energy measures}

Ruminal methane emission in MJ/day was similar between levels of intake in periods 1 and 2 and greater for ad libitum intake than for intake near $\mathrm{ME}_{\mathrm{m}}$ in period 3 (Tables 4 and 5). Relative to GE intake, methane emission was much greater for ad libitum vs. intake near $\mathrm{ME}_{\mathrm{m}}$ in periods 1 and 2 than in period 3 .

Heat energy while fasting and consuming feed near $\mathrm{ME}_{\mathrm{m}}$ and the $\mathrm{ME}_{\mathrm{m}}$ estimate were affected by gender $\times$ period interactions $(P<0.05)$, without any factor impacting $\mathrm{k}_{\mathrm{m}}(\mathrm{P}>0.05$; Table 6$)$. The $\mathrm{ME}_{\mathrm{m}}$ estimate for each gender linearly increased $(\mathrm{P}<0.02)$ as period advanced, although values were fairly similar among genders in period 1 and increased relatively more as time progressed for males than for doelings or wethers. The $\mathrm{ME}_{\mathrm{m}}$ values in period $6(424,595$, and $435 \mathrm{~kJ} /$ $\mathrm{kg} \mathrm{BW}^{0.75}$ for doelings, males, and wethers, respectively; $\mathrm{SE}=38.5$ ) were similar to those in period $4(\mathrm{P}=0.819)$ and the gender $\times$ period interaction was not significant $(\mathrm{P}=0.913)$.

Heat energy with ad libitum intake was greater $(P<0.05)$ for males than for doelings and wethers and was less in periods 2 and 3 than in period 1 (linear and quadratic $P$ values of $<0.001$ and $=0.002$, respectively). The estimate of $\mathrm{ME}_{\mathrm{g}}$ was not different among genders $(\mathrm{P}=0.741)$ and was greatest among periods in period 1 (linear and quadratic changes, $\mathrm{P}<0.001)$. The $\mathrm{k}_{\mathrm{g}}$ tended $(\mathrm{P}=0.067)$ to differ among genders, numerically ranking doelings $>$ wethers $>$ males. Also, $\mathrm{k}_{\mathrm{g}}$ changed quadratically with increasing period $(\mathrm{P}=0.049)$, decreasing from period 1-2 and then increasing in period 3 to a value similar to that in period 1 .

Variation in FHE among animal-period observations differed among 
Table 5

Effects of gender and age on intake and digestion in Boer goats.

\begin{tabular}{|c|c|c|c|c|c|c|c|c|c|c|c|c|c|}
\hline \multirow[b]{2}{*}{ Item } & \multicolumn{2}{|c|}{ Interaction $^{1}$} & \multicolumn{3}{|c|}{ Gender $^{2}$} & \multirow[b]{2}{*}{ SE } & \multicolumn{3}{|c|}{ Period $^{3,4}$} & \multirow[b]{2}{*}{ SE } & \multicolumn{2}{|c|}{ Intake level $^{5}$} & \\
\hline & $\mathrm{GN}$ & IL & $\mathrm{D}$ & M & $\mathrm{W}$ & & 1 & 2 & 3 & & $\mathrm{AL}$ & $\mathrm{MN}$ & SE \\
\hline DM & & & & & & & & & & & & & \\
\hline Intake (g/day) & $\mathrm{D}$ & & & & & & & & & & 1126 & 707 & 50.6 \\
\hline & M & & & & & & & & & & 1494 & 889 & \\
\hline & $\mathrm{W}$ & & & & & & & & & & 1225 & 776 & \\
\hline & & $\mathrm{AL}$ & & & & & 1161 & 1127 & 1569 & 38.6 & & & \\
\hline & & $\mathrm{MN}$ & & & & & 569 & 772 & 1031 & & & & \\
\hline Digestion (\%) & & & $63.6^{\mathrm{ab}}$ & $62.6^{\mathrm{a}}$ & $64.8^{\mathrm{b}}$ & 0.544 & 63.6 & 63.8 & 63.7 & 0.50 & 60.1 & 67.3 & 0.42 \\
\hline Digestion (g/day) & $\mathrm{D}$ & & & & & & 458 & 551 & 714 & 33.3 & 675 & 473 & 31.0 \\
\hline & M & & & & & & 584 & 671 & 953 & & 879 & 593 & \\
\hline & $\mathrm{W}$ & & & & & & 559 & 566 & 788 & & 749 & 527 & \\
\hline & & $\mathrm{AL}$ & & & & & 683 & 671 & 950 & 22.8 & & & \\
\hline & & MN & & & & & 385 & 521 & 687 & & & & \\
\hline $\mathrm{OM}$ & & & & & & & & & & & & & \\
\hline Intake (g/day) & $\mathrm{D}$ & & & & & & & & & & 1039 & 652 & 46.6 \\
\hline & M & & & & & & & & & & 1377 & 820 & \\
\hline & $\mathrm{W}$ & & & & & & & & & & 1129 & 715 & \\
\hline & & $\mathrm{AL}$ & & & & & 1062 & 1037 & 1445 & 35.5 & & & \\
\hline & & $\mathrm{MN}$ & & & & & 526 & 711 & 950 & & & & \\
\hline Digestion (\%) & & & $64.9^{\mathrm{ab}}$ & $63.5^{\mathrm{a}}$ & $66.0^{\mathrm{b}}$ & 0.53 & 64.5 & 64.7 & 65.2 & 0.41 & 61.1 & 68.6 & 0.41 \\
\hline Digestion (g/day) & $\mathrm{D}$ & & & & & & 430 & 516 & 675 & 31.0 & 635 & 446 & 28.8 \\
\hline & M & & & & & & 546 & 624 & 894 & & 821 & 555 & \\
\hline & $\mathrm{W}$ & & & & & & 522 & 530 & 745 & & 702 & 495 & \\
\hline & & $\mathrm{AL}$ & & & & & 638 & 626 & 895 & 21.2 & & & \\
\hline & & $\mathrm{MN}$ & & & & & 361 & 487 & 648 & & & & \\
\hline Gross energy & & & & & & & & & & & & & \\
\hline Intake (MJ/day) & $\mathrm{D}$ & & & & & & & & & & 19.89 & 12.49 & 0.892 \\
\hline & M & & & & & & & & & & 26.39 & 15.72 & \\
\hline & $\mathrm{W}$ & & & & & & & & & & 21.64 & 13.71 & \\
\hline & & $\mathrm{AL}$ & & & & & 20.11 & 19.67 & 28.14 & 0.681 & & & \\
\hline & & $\mathrm{MN}$ & & & & & 9.95 & 13.48 & 18.49 & & & & \\
\hline Digestion (\%) & & & $63.0^{\mathrm{b}}$ & $61.5^{\mathrm{a}}$ & $64.0^{\mathrm{b}}$ & 0.52 & & & & & & & \\
\hline & & $\mathrm{AL}$ & & & & & 57.4 & 58.5 & 60.3 & 0.71 & & & \\
\hline & & $\mathrm{MN}$ & & & & & 67.2 & 67.7 & 65.8 & & & & \\
\hline Digestion (MJ/day) & $\mathrm{D}$ & & & & & & 7.83 & 9.56 & 12.76 & 0.572 & & & \\
\hline & M & & & & & & 9.91 & 11.51 & 16.84 & & & & \\
\hline & $\mathrm{W}$ & & & & & & 9.54 & 9.71 & 14.04 & & & & \\
\hline & & $\mathrm{AL}$ & & & & & 11.51 & 11.41 & 16.92 & 0.393 & & & \\
\hline & & $\mathrm{MN}$ & & & & & 6.67 & 9.12 & 12.17 & & & & \\
\hline Methane & & & & & & & & & & & & & \\
\hline MJ/day & & & 0.93 & 1.17 & 1.02 & 0.075 & & & & & & & \\
\hline & & $\mathrm{AL}$ & & & & & 0.64 & 1.04 & 1.59 & 0.075 & & & \\
\hline & & MN & & & & & 0.63 & 1.07 & 1.25 & & & & \\
\hline$\%$ gross energy intake & & & 5.9 & 5.8 & 6.1 & 0.29 & & & & & & & \\
\hline & & $\mathrm{AL}$ & & & & & 3.1 & 5.2 & 5.7 & 0.37 & & & \\
\hline & & MN & & & & & 6.5 & 8.3 & 6.8 & & & & \\
\hline ME & & & & & & & & & & & & & \\
\hline Intake (MJ/day) & $\mathrm{D}$ & & & & & & 6.80 & 8.09 & 10.85 & 0.494 & 10.19 & 6.98 & 0.456 \\
\hline & M & & & & & & 8.77 & 9.77 & 14.40 & & 13.32 & 8.64 & \\
\hline & $\mathrm{W}$ & & & & & & 8.52 & 8.16 & 11.71 & & 11.24 & 7.68 & \\
\hline & & $\mathrm{AL}$ & & & & & 10.47 & 9.83 & 14.44 & 0.342 & & & \\
\hline & & $\mathrm{MN}$ & & & & & 5.59 & 7.51 & 10.20 & & & & \\
\hline Intake $\left(\mathrm{kJ} / \mathrm{kg} \mathrm{BW} \mathrm{BW}^{0.75}\right)$ & & & 655 & 668 & 653 & 18.5 & & & & & & & \\
\hline & & $\mathrm{AL}$ & & & & & 1014 & 682 & 707 & 19.9 & & & \\
\hline & & $\mathrm{MN}$ & & & & & 528 & 520 & 500 & & & & \\
\hline Concentration (MJ/kg DM) & & & 9.49 & 9.27 & 9.57 & 0.126 & 9.48 & 9.28 & 9.58 & 0.115 & 9.06 & 9.83 & 0.096 \\
\hline $\mathrm{CP}$ & & & & & & & & & & & & & \\
\hline Intake (g/day) & $\mathrm{D}$ & & & & & & 117 & 137 & 196 & 9.0 & 184 & 116 & 8.2 \\
\hline & M & & & & & & 154 & 168 & 263 & & 244 & 146 & \\
\hline & $\mathrm{W}$ & & & & & & 136 & 138 & 217 & & 200 & 127 & \\
\hline & & $\mathrm{AL}$ & & & & & 181 & 175 & 272 & 6.3 & & & \\
\hline & & $\mathrm{MN}$ & & & & & 90 & 120 & 179 & & & & \\
\hline Digestion (\%) & & & 64.9 & 64.0 & 66.2 & 0.77 & 63.9 & 60.5 & 70.7 & 0.68 & 65.4 & 64.7 & 0.58 \\
\hline Digestion (g/day) & $\mathrm{D}$ & & & & & & 74 & 84 & 138 & 6.0 & 123 & 75 & 5.6 \\
\hline & M & & & & & & 95 & 100 & 186 & & 159 & 95 & \\
\hline & $\mathrm{W}$ & & & & & & 91 & 83 & 155 & & 134 & 85 & \\
\hline & & $\mathrm{AL}$ & & & & & 117 & 105 & 194 & 4.3 & & & \\
\hline & & $\mathrm{MN}$ & & & & & 57 & 73 & 125 & & & & \\
\hline NDF & & & & & & & & & & & & & \\
\hline Intake (g/day) & $\mathrm{D}$ & & & & & & & & & & 515 & 325 & 23.3 \\
\hline
\end{tabular}




\begin{tabular}{|c|c|c|c|c|c|c|c|c|c|c|c|c|c|}
\hline \multirow[b]{2}{*}{ Item } & \multicolumn{2}{|c|}{ Interaction $^{1}$} & \multicolumn{3}{|c|}{ Gender $^{2}$} & \multirow[b]{2}{*}{ SE } & \multicolumn{3}{|c|}{ Period $^{3,4}$} & \multirow[b]{2}{*}{ SE } & \multicolumn{2}{|c|}{ Intake level $^{5}$} & \multirow[b]{2}{*}{ SE } \\
\hline & GN & IL & $\mathrm{D}$ & M & $\mathrm{W}$ & & 1 & 2 & 3 & & $\mathrm{AL}$ & $\mathrm{MN}$ & \\
\hline & M & & & & & & & & & & 688 & 410 & \\
\hline & $\mathrm{W}$ & & & & & & & & & & 564 & 358 & \\
\hline & & $\mathrm{AL}$ & & & & & 526 & 531 & 710 & 17.8 & & & \\
\hline & & $\mathrm{MN}$ & & & & & 260 & 365 & 467 & & & & \\
\hline \multirow[t]{3}{*}{ Digestion (\%) } & & & 47.8 & 46.7 & 51.1 & 0.90 & & & & & & & \\
\hline & & $\mathrm{AL}$ & & & & & 36.8 & 44.3 & 42.7 & 1.15 & & & \\
\hline & & $\mathrm{MN}$ & & & & & 55.6 & 59.1 & 52.6 & & & & \\
\hline \multirow[t]{5}{*}{ Digestion (g/day) } & $\mathrm{D}$ & & & & & & 140 & 205 & 234 & 11.5 & & & \\
\hline & M & & & & & & 175 & 244 & 318 & & & & \\
\hline & $\mathrm{W}$ & & & & & & 187 & 220 & 269 & & & & \\
\hline & & $\mathrm{AL}$ & & & & & 191 & 230 & 301 & 7.9 & & & \\
\hline & & MN & & & & & 144 & 216 & 246 & & & & \\
\hline \multicolumn{14}{|c|}{ Nitrogen balance ( $\mathrm{g} /$ day) } \\
\hline & & & & & & & & & & & 16.1 & 9.0 & 0.54 \\
\hline & $\mathrm{D}$ & & & & & & 7.8 & 8.9 & 17.4 & 1.10 & & & \\
\hline & M & & & & & & 9.7 & 11.0 & 24.2 & & & & \\
\hline & $\mathrm{W}$ & & & & & & 8.4 & 7.8 & 17.6 & & & & \\
\hline
\end{tabular}

a,b Gender means without a common superscript letter differ $(\mathrm{P}<0.05)$.

${ }^{1} \mathrm{GN}=$ gender; $\mathrm{IL}=$ intake level.

${ }^{2} \mathrm{D}=$ doeling; $\mathrm{M}=$ male; $\mathrm{W}=$ wether.

${ }^{3}$ Measurement periods consisted of three segments of 12,10 , and 4 days for consumption ad libitum and near the ME requirement for maintenance and while fasting, respectively.

${ }^{4}$ Maintenance segment measures began at 4.9, 7.8, and 11.7 mo of age in periods 1,2 , and 3, respectively.

${ }^{5} \mathrm{AL}=$ ad libitum; $\mathrm{MN}=$ near the ME requirement for maintenance.

genders $(\mathrm{P}<0.001)$, which was also the case for animal-gender observations in the different periods $(\mathrm{P}=0.004$; Table 7$)$. Based on overall SD for gender and period and for the genders in each period, variability was greater for males than for doelings and wethers and greatest among periods in period 4 . Variability in $\mathrm{k}_{\mathrm{m}}$ was also greater in periods 1 and 4 vs. periods 2 and 3 but was not different among genders $(\mathrm{P}=0.748)$. Overall, variability in $\mathrm{ME}_{\mathrm{m}}$ also was greatest among genders for males, although differences were somewhat greater in periods 2 and 3 than in periods 1 and 4 . Variability in $k_{g}$ also differed among genders, being lowest for doelings.

The $\mathrm{P}$ values of $\mathrm{BW}, \mathrm{BW}^{2}$, and $\mathrm{BW}^{3}$ in regressions against $\mathrm{HE}$ in $\mathrm{MJ} /$ day at the three different levels of intake were $0.055,0.225$, and 0.162 , with an $\mathrm{R}^{2}$ of 0.598 . Inclusion of fixed effects of level of intake, gender, and their interaction $(\mathrm{P}<0.001,<0.001$, and 0.001$)$ resulted in $\mathrm{P}$ values of $0.033,0.828$, and 0.560 for $\mathrm{BW}, \mathrm{BW}^{2}$, and $\mathrm{BW}^{3}$, respectively, with a greater $\mathrm{R}^{2}$ of 0.938 . Regressions of HE by level of intake and gender resulted in nonsignificant coefficients for the linear, quadratic, and cubic BW functions $(P \geq 0.099)$. However, similar to the regression noted above, inclusion in the model of gender $(\mathrm{P}<0.001)$ resulted in $\mathrm{P}$ values of $0.025,0.211$, and 0.133 for $\mathrm{BW}, \mathrm{BW}^{2}$, and $\mathrm{BW}^{3}$, respectively, with a $\mathrm{R}^{2}$ of 0.927 .

Fasting HE in period 1 was correlated with that in period $3(\mathrm{r}=0.55$; $\mathrm{P}=0.008)$. There were correlations between FHE in period 2 and periods $3(\mathrm{r}=0.59 ; \mathrm{P}=0.004)$ and $4(\mathrm{r}=0.65 ; \mathrm{P}=0.003)$ and between

Table 6

Effects of gender and age on energy measures of Boer goats.

\begin{tabular}{|c|c|c|c|c|c|c|c|c|c|c|c|c|c|c|c|c|}
\hline \multirow[b]{2}{*}{ Item $^{6}$} & \multicolumn{3}{|c|}{ Effect P value ${ }^{1}$} & \multirow[b]{2}{*}{ GN } & \multicolumn{3}{|c|}{ Period contrast $\mathrm{P}$ values ${ }^{2}$} & \multicolumn{3}{|c|}{ Gender $^{3}$} & \multirow[b]{2}{*}{ SE } & \multicolumn{4}{|c|}{ Period $^{4,5}$} & \multirow[b]{2}{*}{ SE } \\
\hline & GN & PR & $\mathrm{GN} * \mathrm{PR}$ & & Linear & Quadratic & Cubic & $\mathrm{D}$ & M & $\mathrm{W}$ & & 1 & 2 & 3 & 4 & \\
\hline \multicolumn{17}{|l|}{$\mathrm{HE}\left(\mathrm{kJ} / \mathrm{kg} \mathrm{BW}{ }^{0.75}\right)$} \\
\hline \multirow[t]{3}{*}{ Fasting } & $<0.001$ & $<0.001$ & $<0.001$ & $\mathrm{D}$ & 0.576 & 0.774 & 0.549 & & & & & 277 & 272 & 281 & 281 & 10.1 \\
\hline & & & & M & $<0.001$ & 0.170 & 0.030 & & & & & 288 & 327 & 334 & 398 & \\
\hline & & & & $\mathrm{W}$ & 0.128 & 0.918 & 0.004 & & & & & 274 & 303 & 274 & 305 & \\
\hline \multirow[t]{3}{*}{ Intake near $\mathrm{ME}_{\mathrm{m}}$} & $<0.001$ & $<0.001$ & 0.003 & $\mathrm{D}$ & 0.223 & 0.719 & 0.512 & & & & & 419 & 432 & 429 & 436 & 10.2 \\
\hline & & & & M & $<0.001$ & 0.834 & 0.223 & & & & & 444 & 480 & 494 & 534 & \\
\hline & & & & $\mathrm{W}$ & 0.089 & 0.287 & 0.825 & & & & & 426 & 442 & 452 & 447 & \\
\hline Ad libitum intake & $<0.001$ & $<0.001$ & 0.672 & & $<0.001$ & 0.002 & & $540^{\mathrm{a}}$ & $635^{\mathrm{b}}$ & $569^{\mathrm{a}}$ & 11.8 & 636 & 551 & 557 & & 11.4 \\
\hline $\mathrm{k}_{\mathrm{m}}$ & 0.909 & 0.126 & 0.330 & & 0.097 & 0.406 & 0.147 & 70.2 & 69.5 & 69.7 & 1.25 & 71.3 & 70.9 & 67.7 & 69.3 & 1.27 \\
\hline \multirow[t]{3}{*}{$\mathrm{ME}_{\mathrm{m}}\left(\mathrm{kJ} / \mathrm{kg} \mathrm{BW}^{0.75}\right)$} & $<0.001$ & $<0.001$ & $<0.001$ & $\mathrm{D}$ & 0.016 & 0.567 & 0.764 & & & & & 382 & 390 & 399 & 420 & 14.2 \\
\hline & & & & M & $<0.001$ & 0.381 & 0.083 & & & & & 412 & 469 & 492 & 569 & \\
\hline & & & & $\mathrm{W}$ & 0.002 & 0.425 & 0.594 & & & & & 384 & 417 & 426 & 439 & \\
\hline $\mathrm{ME}_{\mathrm{g}}\left(\mathrm{kJ} / \mathrm{kg} \mathrm{BW} \mathrm{W}^{0.75}\right)$ & 0.741 & $<0.001$ & 0.066 & & $<0.001$ & $<0.001$ & & 398 & 367 & 383 & 30.6 & 618 & 259 & 268 & & 27.7 \\
\hline $\mathrm{k}_{\mathrm{g}}$ & 0.067 & 0.049 & 0.169 & & 0.502 & 0.017 & & 61.5 & 48.1 & 52.7 & 3.91 & $58.8^{\mathrm{b}}$ & $47.8^{\mathrm{a}}$ & $55.8^{\mathrm{ab}}$ & & 3.37 \\
\hline
\end{tabular}

${ }^{\mathrm{a}, \mathrm{b}}$ Gender means without a common superscript letter differ $(\mathrm{P}<0.05)$.

${ }^{1} \mathrm{GN}=$ gender; $\mathrm{PR}=$ period.

${ }^{2}$ Linear, quadratic, and cubic effects of period.

${ }^{3} \mathrm{D}$ = doeling; $\mathrm{M}=$ male; $\mathrm{W}$ = wether.

${ }^{4}$ Measurement periods consisted of three segments of 12,10 , and 4 days for consumption ad libitum and near the ME requirement for maintenance and while fasting, respectively.

${ }^{5}$ Maintenance segment measures began at 4.9, 7.8, 11.7, and 14.8 mo of age in period 1, 2, 3, and 4, respectively.

${ }^{6} \mathrm{HE}=$ heat energy; $\mathrm{ME}_{\mathrm{m}}=\mathrm{ME}$ requirement for maintenance; $\mathrm{k}_{\mathrm{m}}=$ efficiency of $\mathrm{ME}$ utilization for maintenance; $\mathrm{ME} \mathrm{g}_{\mathrm{g}}=\mathrm{ME}$ requirement for gain; $\mathrm{k}_{\mathrm{g}}=$ efficiency of energy utilization for gain. 
Table 7

Homogeneity of variance for energy measures of Boer goats.

\begin{tabular}{|c|c|c|c|c|c|c|c|c|c|c|c|c|c|c|}
\hline \multirow[b]{2}{*}{ Item $^{\mathrm{a}}$} & \multicolumn{2}{|c|}{ Bartlett test $\mathrm{P}$ value } & \multicolumn{4}{|c|}{ Gender Bartlett test $\mathrm{P}$ value for periods } & \multirow[b]{2}{*}{ Period } & \multicolumn{3}{|c|}{ Gender SD } & \multicolumn{4}{|c|}{ Period SD } \\
\hline & Gender & Period & 1 & 2 & 3 & 4 & & $\mathrm{D}$ & M & $\mathrm{W}$ & 1 & 2 & 3 & 4 \\
\hline \multirow[t]{5}{*}{ FHE $\left(\mathrm{kJ} / \mathrm{kg} \mathrm{BW}{ }^{0.75}\right)$} & $<0.001$ & 0.004 & 0.198 & 0.023 & 0.065 & 0.005 & Mean & 17.6 & 55.3 & 23.2 & 29.6 & 31.4 & 36.6 & 59.9 \\
\hline & & & & & & & 1 & 19.1 & 40.5 & 29.4 & & & & \\
\hline & & & & & & & 2 & 11.6 & 33.7 & 15.5 & & & & \\
\hline & & & & & & & 3 & 22.3 & 38.0 & 14.6 & & & & \\
\hline & & & & & & & 4 & 17.4 & 48.5 & 11.8 & & & & \\
\hline $\mathrm{k}_{\mathrm{m}}$ & 0.748 & 0.009 & & & & & & & & & 6.5 & 4.4 & 4.2 & 7.9 \\
\hline \multirow[t]{5}{*}{$\mathrm{ME}_{\mathrm{m}}\left(\mathrm{kJ} / \mathrm{kg} \mathrm{BW}{ }^{0.75}\right)$} & $<0.001$ & $<0.001$ & 0.171 & 0.001 & 0.196 & 0.897 & Mean & 33.2 & 74.1 & 37.2 & 27.0 & 46.2 & 52.1 & 86.8 \\
\hline & & & & & & & 1 & 14.3 & 31.4 & 25.5 & & & & \\
\hline & & & & & & & 2 & 25.6 & 50.0 & 11.1 & & & & \\
\hline & & & & & & & 3 & 27.8 & 50.5 & 27.2 & & & & \\
\hline & & & & & & & 4 & 51.0 & 62.0 & 55.3 & & & & \\
\hline $\mathrm{k}_{\mathrm{g}}$ & 0.004 & 0.378 & & & & & Mean & 9.5 & 16.8 & 20.6 & & & & \\
\hline
\end{tabular}

${ }^{\mathrm{a}} \mathrm{FHE}=$ fasting heat energy; $\mathrm{k}_{\mathrm{m}}=$ efficiency of $\mathrm{ME}$ utilization for maintenance; $\mathrm{ME}_{\mathrm{m}}=\mathrm{ME}$ requirement for maintenance; $\mathrm{k}_{\mathrm{g}}=$ efficiency of energy utilization for gain.

period 3 and 4 measures $(\mathrm{r}=0.62 ; \mathrm{P}=0.004)$. No significant correlations were noted among period $\mathrm{k}_{\mathrm{m}}$ measures. Nonetheless, $\mathrm{ME}_{\mathrm{m}}$ estimates in each period were correlated, with $\mathrm{r}$ of $0.66(\mathrm{P}=0.001)$, $0.53(\mathrm{P}=0.011), 0.63(\mathrm{P}=0.004), 0.75(\mathrm{P}<0.001), 0.79(\mathrm{P}<0.001)$, and $0.76(\mathrm{P}<0.001)$ between periods $1-2,1-3,1-4,2-3,2-4$, and $3-4$, respectively. In contrast to the lack of relationship between $\mathrm{k}_{\mathrm{m}}$ in different periods, $\mathrm{k}_{\mathrm{g}}$ in period 3 was moderately correlated with estimates in periods $1(\mathrm{r}=0.35 ; \mathrm{P}=0.006)$ and $2(\mathrm{r}=0.30$; $\mathrm{P}=0.017$ ). Estimates of $\mathrm{k}_{\mathrm{m}}$ and $\mathrm{k}_{\mathrm{g}}$ in the same period were not significantly related, as was true for $\mathrm{ME}_{\mathrm{m}}$ and $\mathrm{k}_{\mathrm{g}}$ except for a moderate negative correlation in period $2(\mathrm{r}=-0.26 ; \mathrm{P}=0.048)$.

\section{Discussion}

\subsection{Diet, $A D G$, and $B W$}

The diet has been previously used in meat goat buck performance tests of Langston University (Hu et al., 2012) and studies of Ngwa et al. (2007, 2009). Even with the segments of intake near $\mathrm{ME}_{\mathrm{m}}$, fasting, and realimentation, it facilitated moderate ADG through period 4 and greater ADG by males than doelings and wethers in three and two periods, respectively. It is not clear why the magnitude of the gender difference was greatest in period 3. Similar ADG among genders in period 4 may reflect the relatively high stage of maturity and smaller differences in composition of tissue accreted than earlier, particularly in periods 1 and 2. Relatedly, BW in periods 1, 2, and 3 was 34-36, 52-54, and $81-88 \%$ of that in period 4 , respectively. Hence, with growth rates of this experiment, it would appear that the genders were at fairly similar stages of maturity.

The lack of significant cubic effects of BW in regressions against HE in MJ/day suggest that optimal body size, as addressed by Hannon and Murphy (2016), was not exceeded at any age. This is in accordance with moderate ADG, implying that fat accretion was not particularly high. Although, composition of the whole body and tissue accreted would have most likely differed among genders to some extent as expected based on studies such as Almeida et al. $(2015,2016)$. That a level of ad libitum feed intake adequately above that near $\mathrm{ME}_{\mathrm{m}}$ was not achieved in period 4 but could be earlier also supports BW not greater than optimal size.

\subsection{Intake and digestion}

Magnitudes of difference in DM intake between levels of intake (i.e., ad libitum and near $\mathrm{ME}_{\mathrm{m}}$ ) for the genders (averaging 419, 605, and $449 \mathrm{~g} /$ day for doelings, males, and wethers, respectively) were in accordance with expected differences in potential for BW gain and nutrient and energy use. It is not clear why the difference between levels of intake was less in period 2 (355 g/day) than periods 1 (592 g/ day) and 3 (538 g/day), although this could have resulted in compensatory growth potential and highest ADG in period 3. Slightly lower digestibility for males than for doelings, except of $\mathrm{CP}$, presumably relates to shorter ruminal digesta residence time because of high DM intake by males (Leite et al., 2015a, 2015b). This also should be primarily responsible for considerably lower digestibility, other than $\mathrm{CP}$, with ad libitum than near $\mathrm{ME}_{\mathrm{m}}$ intake.

\section{3. $M E_{m}$}

Some sets of recommendations of nutrient requirements for small ruminants entail lower $\mathrm{ME}_{\mathrm{m}}$ for mature than for growing animals or decreases with increasing age and stage of maturity (e.g., SCA, 1990; NRC, 2007; Small Ruminant Nutrition System, Tedeschi et al., 2010). It is possible that with greater ages this would have been noted in the present experiment as well. However, here $\mathrm{ME}_{\mathrm{m}}$ of doelings and wethers in fact linearly increased at a relatively slow rate as the experiment progressed, with values at each time fairly similar between genders. This latter aspect agrees with many recommendations, including those of NRC (2007), AFRC (1998), SCA (1990), and Tedeschi et al. (2010).

Greater $\mathrm{ME}_{\mathrm{m}}$ for males vs. doelings and wethers in periods 2, 3, and 4 , as well as in period 6 , is in general agreement with assumptions of some sets of recommendations, such as a $15 \%$ difference (SCA, 1990; NRC, 2007), but the magnitude increased with advancing time. Factors responsible for this finding are unclear, yet some potentially involved issues can be addressed. One consideration is that composition of the whole body and tissue being accreted was probably fairly similar among genders in period 1 at a young age and when BW was not markedly different (Almeida et al., 2015), with greater differences anticipated in periods 2 and 3 (Almeida et al., 2016). Perhaps with the relatively high stage of maturity in period 4 during the period of measurement the composition of any accreted tissue was similar among genders. In regards to the substantial gender difference in period 4, animals were maintained in gender groups in the same facility, although the male pen was not adjacent to that of these or other female goats, without direct fenceline contact. Furthermore, period 4 measures occurred in mid- to late summer when some female goats at the University farm may have begun cycling, which could have caused behavior of males that contributed to elevated $\mathrm{HE}$ and $\mathrm{ME}_{\mathrm{m}}$. However, that $\mathrm{ME}_{\mathrm{m}}$ of males was numerically $26 \mathrm{~kJ} / \mathrm{kg} \mathrm{BW}{ }^{0.75}$ greater in period 6 vs. 4 suggests that if this factor did have influence in period 4 , a similar effect occurred approximately 1 yr later in period 6 .

Without considering periods 4 or 6 , the $\mathrm{ME}_{\mathrm{m}}$ of males averaged $14.5 \%$ greater than the average for doelings and wethers. Relating to the magnitude of difference, there was consideration given for applying 
unique levels of intake near $\mathrm{ME}_{\mathrm{m}}$ to the genders. But, if a level greater for males than doelings or wethers had been used, such as 15\% of SCA (1990) and NRC (2007), gender $\mathrm{ME}_{\mathrm{m}}$ estimates could be considered confounded. Moreover, use of the same near $\mathrm{ME}_{\mathrm{m}}$ level of intake might have lessened male $\mathrm{HE}$ compared with a higher near $\mathrm{ME}_{\mathrm{m}}$ intake level, thereby increasing $\mathrm{k}_{\mathrm{m}}$ and minimizing $\mathrm{ME}_{\mathrm{m}}$ and differences from doelings and wethers.

Based on the homogeneity of variance analysis, males appeared considerably more variable in $\mathrm{ME}_{\mathrm{m}}$ than females and wethers because of FHE rather than $\mathrm{k}_{\mathrm{m}}$. This might relate to differences among individuals in rates of maturation, encompassing impact on body composition as well as other physiological conditions affecting basal metabolic rate. Differences in such factors seem less important at a young age as in period 1 than later when older.

\section{4. $k_{m}$ and $k_{g}$}

The $\mathrm{k}_{\mathrm{m}}$ estimates were in close accordance with prediction based on the AFRC $(1998)$ equation of $(0.35 \times q)+0.503$, with q being ME intake relative to GE intake as a fraction (i.e., 0.511 and 0.556 with intake ad libitum and near $\mathrm{ME}_{\mathrm{m}}$, respectively) and predicted values of $68.2 \%$ and $69.8 \%$, respectively. Estimates of $\mathrm{k}_{\mathrm{g}}$ were considerably more variable than those of $\mathrm{k}_{\mathrm{m}}$, concomitant with numerical differences among genders in line with findings of Almeida et al. (2015) and a lower value in period 2 than 1 , for which factors responsible are unclear. Moreover, the AFRC $(1998)$ equation of $(0.024 \times q)+0.465$ predicted $\mathrm{k}_{\mathrm{g}}$ of $48 \%$, similar to that noted for males and period 2 but lower than for other estimates. The $\mathrm{k}_{\mathrm{g}}$ determined by Almeida et al. (2015) for Saanen goats initially at 9.2 mo of age and $30 \mathrm{~kg}$ BW varied among genders as seen in the present experiment, although magnitudes of difference were much greater (i.e., $55 \%, 32 \%$, and $40 \%$ for doelings, males, and wethers, respectively). Almeida et al. (2015) also applied these $\mathrm{k}_{\mathrm{g}}$ to the composition of empty BW gain at the highest BW, yielding $\mathrm{ME}_{\mathrm{g}}(53.8,52.4$, and $46.9 \mathrm{MJ} / \mathrm{kg}$ empty BW gain for doelings, males, and wethers, respectively) much greater than values suggested by NRC (2007) even for mature goats. Perhaps this involves relatively high fat deposition at that time as well as low estimates of $\mathrm{ME}_{\mathrm{m}}$ relative to other procedures, as addressed later. Although corresponding values could be determined in the present experiment, their value would be questionable considering that ADG encompasses periods of time with intake near $\mathrm{ME}_{\mathrm{m}}$, while fasting, and during realimentation.

\subsection{Energy measure relationships}

Relationships noted between energy measures in the periods entail influence of maintenance over time of differences among genders and individuals within gender. Nonetheless, it would appear that animals with relatively low, moderate, or high $\mathrm{ME}_{\mathrm{m}}$ tended to remain as such throughout the study largely because of differences in FHE rather than $\mathrm{k}_{\mathrm{m}}$. Pelletizing and the associated small particle size of the diet might have contributed to little variability among animals in mass and energy use by the gastrointestinal tract (Goetsch, 1998) to minimize differences in $k_{\mathrm{m}}$. Although only one goat breed was used, the lack of correlation between $\mathrm{k}_{\mathrm{m}}$ and $\mathrm{k}_{\mathrm{g}}$, as was also generally true for $\mathrm{ME}_{\mathrm{m}}$ and $\mathrm{k}_{\mathrm{g}}$, could support the postulate that the greater capacity for growth and mature size of Boer goats compared with other meat breeds such as Spanish of the USA is not accompanied by a greater $\mathrm{ME}_{\mathrm{m}}$ requirement (Ngwa et al., 2009; Asmare et al., 2012).

\subsection{Study conditions}

Little attention has been given thus far to absolute values of FHE, $\mathrm{k}_{\mathrm{m}}, \mathrm{ME}_{\mathrm{m}}$, and $\mathrm{k}_{\mathrm{g}}$ because of many influencing factors that make direct comparisons of estimates from different studies challenging. For example, the $412 \mathrm{~kJ} / \mathrm{kg} \mathrm{BW} \mathrm{BW}^{0.75} \mathrm{ME}_{\mathrm{m}}$ estimate of Almeida et al. (2015) for Saanen doelings, males, and wethers from 30 to $45 \mathrm{~kg}$ BW with ad libitum intake was similar to some values in the present experiment but lower and greater than others. The $\mathrm{k}_{\mathrm{m}}$ of Almeida et al. (2015; 62.7\%) was less than found in this experiment as well. Animal age and activity and estimation procedures are among conditions that may have contributed to such differences.

The nature of animal activity and behavior could influence energy measures in experiments like these. During most of this study animals were in groups to simulate common production settings with free movement and socialization when not used for measurements, whereas housing in the study of Almeida et al. (2015) was not specifically stated though could have been on an individual animal basis. Animals in the present experiment were not grazing; however, some previous studies suggest impact of the experimental setting on basal metabolic rate throughout the day regardless of the specific activity an animal might be engaged in at a particular point in time (Patra et al., 2008a, 2008b; Tovar-Luna et al., 2011; Brassard et al., 2016).

Animals of the different genders were of similar age in this study and that of Almeida et al. (2015), but pre-trial management apparently differed. That is, BW of genders in the present experiment was allowed to vary, but that of Saanen goats of each gender used by Almeida et al. (2015) was $30 \mathrm{~kg}$ at an average initial age of $9.2 \mathrm{mo}$. This implies an ADG of approximately $96 \mathrm{~g}$ from birth at an assumed BW of $3 \mathrm{~kg}$ to the start of the experiment for each gender, suggesting a lower pre-trial plane of nutrition for males that could have impacted later measurements (Asmare et al., 2006; Tovar-Luna et al., 2007; Helal et al., 2011; Goetsch et al., 2017).

With estimation of FHE by Almeida et al. (2015) based on RE determined with ad libitum intake and levels $25 \%$ and $50 \%$ less, both FHE and $k_{m}$ should be less than in experiments like the present because of different contributions to $\mathrm{HE}$ of metabolism of energy from the diet and mobilized tissue at the different levels of intake, even though quality of the diet used by Almeida et al. (2015) may have been greater. In addition, subjecting the same animals in the present experiment to the different levels of intake in sequential segments would have had effects different from those with constant levels of intake over entire, relatively short-term experiments such as that of Almeida et al. (2015). As supported by findings of Tovar-Luna et al. (2010) with lactating Alpine goats, measures in the latter part of the intake near $\mathrm{ME}_{\mathrm{m}}$ segment of the present experiment were most likely still influenced by earlier ad libitum intake, with elevated HE compared with continuous near $\mathrm{ME}_{\mathrm{m}}$ intake, which was presumably also true for the subsequent fasting segment. Hence, the approach of the present experiment should yield higher $\mathrm{ME}_{\mathrm{m}}$ estimates than comparative slaughter with three levels of intake without fasting, with concomitant effect on $\mathrm{k}_{\mathrm{g}}$ and $\mathrm{ME}_{\mathrm{g}}$.

\section{Conclusions}

As age of Boer goats increased from approximately 5 to 15 mo with a moderate rate of growth, $\mathrm{ME}_{\mathrm{m}}$ was fairly similar for doelings and wethers and increased with advancing time at a relatively slow rate (e.g., $4 \mathrm{~kJ} / \mathrm{kg} \mathrm{BW}^{0.75}$ per month). The $\mathrm{ME}_{\mathrm{m}}$ of males at 5,8 , and $12 \mathrm{mo}$ was $14.5 \%$ greater than the average of doelings and wethers, but with a greater rate of increase with increasing age and a much greater value at 15 mo (i.e., 32\%).

\section{Conflicts of interest}

There are no conflicts of interest.

\section{Acknowledgements}

The project was supported by the USDA National Institute for Food and Agriculture (NIFA) Evans-Allen Project OKLXSAHLU2012, Accession Number 0228824. 


\section{References}

AFRC, 1998. The Nutrition of Goats. CAB International, New York, NY, USA.

Almeida, A.K., Resende, K.T., St-Pierre, N., Silva, S.P., Soares, D.C., Fernandes, M.H.M.R., Souza, A.P., Silva, N.C.D., Lima, A.R.C., Teixeira, I.A.M.A., 2015. Energy requirements for growth in male and female Saanen goats. J. Anim. Sci. 93, 3932-3940.

Almeida, A.K., Resende, K.T., Tedeschi, L.O., Fernandes, M.H.M.R., Regadas Filho, J.G.L., Teixeira, I.A.M.A., 2016. Using body composition to determine weight at maturity of male and female Saanen goats. J. Anim. Sci. 94, 2564-2571.

AOAC, 2006. Official Methods of Analysis, 18th ed. AOAC International, Gaithersburg, MD, USA.

Asmare, A., Puchala, R., Merkel, R.C., Sahlu, T., Goetsch, A.L., 2006. Changes in energy expenditure by meat goats with varying levels of feed intake near maintenance and below. J. Appl. Anim. Res. 29, 81-89.

Asmare, A., Puchala, R., Tesfai, K., Detweiler, G.D., Dawson, L.J., Askar, A.R., Sahlu, T., Wang, Z., Goetsch, A.L., 2012. Effects of small ruminant type and level of intake on metabolism. Small Rumin. Res. 102, 186-190.

Brassard, M.-E., Puchala, R., Gipson, T.A., Goetsch, A.L., 2016. Factors influencing heat energy associated with activity by grazing meat goats. Livest. Sci. 193, 103-109.

Brouwer, E., 1965. Report of sub-committee on constants and factors. In: Blaxter, K.L. ed., Energy Metabolism, Proc. 3rd Symp. European Assoc. Anim. Prod. Publ. No. 11. Academic Press, London, UK. pp. 441-443.

Goetsch, A.L., 1998. Splanchnic tissue energy use in ruminants consuming forage-based diets ad libitum. J. Anim. Sci. 76, 2737-2746.

Goetsch, A.L., Puchala, R., Dolebo, A.T., Gipson, T.A., Tsukahara, Y., Dawson, L.J., 2017. Simple methods to estimate the maintenance feed requirement of small ruminants with different levels of feed restriction. J. Appl. Anim. Res. 45, 104-111.

Hannon, B.M., Murphy, M.R., 2016. Toward a theory of energetically optimal body size in growing animals. J. Anim. Sci. 94, 2532-2541.

Helal, A., Puchala, R., Detweiler, G.D., Gipson, T.A., Sahlu, T., Goetsch, A.L., 2011. Effects of restricted feed intake on energy expenditure by different goat breeds. J. Anim. Sci. $89,4175-4187$.

Hu, W., Gipson, T.A., Hart, S.P., Dawson, L.J., Sahlu, T., Goetsch, A.L., 2012. Optimum duration of performance testing for growth, feed intake, and feed efficiency in growing Boer bucks. Small Rumin. Res. 104, 114-121.

Leite, R.F., Krizsan, S.J., Figueiredo, F.O.M., Carvalho, V.B., Teixeira, I.A.M.A., Huhtanen, P., 2015a. Contribution of different segments of the gastrointestinal tract to digestion in growing Saanen goats. J. Anim. Sci. 93, 1802-1814.

Leite, R.F., Krizsan, S.J., Figueiredo, F.O.M., Carvalho, V.B., Teixeira, I.A.M.A., Huhtanen, P., 2015b. Retention time of digesta in the gastrointestinal tract of growing Saanen goats. J. Anim. Sci. 93, 3969-3978.

Littell, R.C., Milliken, G.A., Stroup, W.W., Wolfinger, R.D., 1996. SAS System for Mixed Models. SAS Institute Inc, Cary, NC, USA.

Ngwa, A.T., Dawson, L.J., Puchala, R., Detweiler, G., Merkel, R.C., Tovar-Luna, I., Sahlu, T., Ferrell, C.L., Goetsch, A.L., 2007. Effect of initial body condition of Boer $\times$ Spanish yearling wethers and level of nutrient intake on body composition. Small Rumin. Res. $73,13-26$.
Ngwa, A.T., Dawson, L.J., Puchala, R., Detweiler, G.D., Merkel, R.C., Wang, Z., Tesfai, K., Sahlu, T., Ferrell, C.L., Goetsch, A.L., 2009. Effects of breed and diet on growth and body composition of crossbred Boer and Spanish wether goats. J. Anim. Sci. 87, 2913-2923.

NRC, 2007. Nutrient Requirements of Small Ruminants: Sheep, Goats, Cervids, and New World Camelids. Natl. Acad. Press, Washington, DC, USA.

Patra, A.K., Puchala, R., Detweiler, G., Dawson, L.J., Sahlu, T., Goetsch, A.L., 2008a. Effects of tethering on forage selection, intake, and digestibility, grazing behavior, and energy expenditure by Boer $\times$ Spanish goats grazing high quality forage. J. Anim. Sci. 86, 1245-1253.

Patra, A.K., Puchala, R., Detweiler, G., Dawson, L.J., Sahlu, T., Goetsch, A.L., 2008b. Tethering meat goats grazing forage of high nutritive value and low to moderate mass. Asian-Aust. J. Anim. Sci. 21, 1252-1261.

Puchala, R., Tovar-Luna, I., Sahlu, T., Freetly, H.C., Goetsch, A.L., 2009. The relationship between heart rate and energy expenditure in growing crossbred Boer and Spanish wethers. J. Anim. Sci. 87, 1714-1721.

Puchala, R., Tovar-Luna, I., Goetsch, A.L., Sahlu, T., Carstens, G.E., Freetly, H.C., 2007. The relationship between heart rate and energy expenditure in Alpine, Angora, Boer and Spanish goat wethers consuming different quality diets at level of intake near maintenance or fasting. Small Rumin. Res. 70, 183-193.

Sahlu, T., Dawson, L.J., Gipson, T.A., Hart, S.P., Merkel, R.C., Puchala, R., Wang, Z., Zeng, S., Goetsch, A.L., 2009. Impact of animal science research on U.S. goat production and predictions for the future. J. Anim. Sci. 87, 400-418.

Sahlu, T., Goetsch, A.L., Luo, J., Nsahlai, I.V., Moore, J.E., Galyean, M.L., Owens, F.N., Ferrell, C.L., Johnson, Z.B., 2004. Energy and protein requirements of goats: developed equations, other considerations and future research to improve them. Small Rumin. Res. 53, 191-220.

SAS, 2004. SAS $/$ STAT $^{*} 9.1$ User's Guide. SAS Inst. Inc., Cary, NC, USA.

SCA, 1990. Feeding Standards for Australian Livestock. Ruminants. Standing Committee on Agriculture and Resource Management. CSIRO Publications, East Melbourne, Australia.

Tedeschi, L.O., Cannas, A., Fox, D.G., 2010. A nutrition mathematical model to account for dietary supply and requirements of energy and other nutrients for domesticated small ruminants: the development and evaluation of the Small ruminant Nutrition System. Small Rumin. Res. 89, 174-184.

Tovar-Luna, I., Goetsch, A.L., Puchala, R., Sahlu, T., Carstens, G.E., Freetly, H.C., Johnson, Z.B., 2007. Effects of moderate feed restriction on energy expenditure by 2 year old crossbred Boer goats. Small Rumin. Res. 72, 25-32.

Tovar-Luna, I., Puchala, R., Sahlu, T., Freetly, H.C., Goetsch, A.L., 2010. Effects of stage of lactation and level of feed intake on energy utilization by Alpine dairy goats. J. Dairy Sci. 93, 4829-4837.

Tovar-Luna, I., Puchala, R., Gipson, T.A., Detweiler, G.D., Dawson, L.J., Sahlu, T., Keli, A., Goetsch, A.L., 2011. Effects of night-locking and stage of production on forage intake, digestion, behavior, and energy utilization by meat goat does grazing grass/legume pasture. Livest. Sci. 40, 225-245.

Van Soest, P.J., Robertson, J.B., Lewis, B.A., 1991. Methods for dietary fiber, neutral detergent fiber and non-starch polysaccharides in relation to animal nutrition. J. Dairy Sci. 74, 3583-3597. 